\title{
Erratum to: Novel function of PIWIL1 in neuronal polarization and migration via regulation of microtubule-associated proteins
}

Ping-ping Zhao ${ }^{1,2}$, Mao-jin Yao ${ }^{1,2}$, Si-yuan Chang ${ }^{1,2}$, Lan-tao Gou ${ }^{2,3}$, Mo-fang Liư ${ }^{3}$, Zi-long Qiu and Xiao-bing Yuan ${ }^{1,4^{*}}$

After publication of this article [1], the authors noticed two errors in Figs. 2e and 3e.

The images provided for Fig. 2e in squares 'Scramble upCP' and 'Scramble IoCP' were incorrect. The correct version of Fig. 2 is included in this erratum.

In Fig. 3e, the label 'RNAi 4' was missing from the $x$ axis. The correct version of Fig. 3 is also included in this erratum.

\begin{abstract}
Author details
${ }^{1}$ Institute of Neuroscience and State Key Laboratory of Neuroscience, Shanghai Institutes for Biological Sciences, Chinese Academy of Sciences, Shanghai 200031, China. ${ }^{2}$ Graduate School of Chinese Academy of Sciences, Shanghai 200031, China. ${ }^{3}$ State Key Laboratory of Molecular Biology, Institute of Biochemistry and Cell Biology, Shanghai Institutes for Biological Sciences, Chinese Academy of Sciences, Shanghai 200031, China. ${ }^{4}$ Current Affiliation: Hussman Institute for Autism, Baltimore, MD 21201, USA.
\end{abstract}

Received: 15 February 2016 Accepted: 15 February 2016

Published online: 23 February 2016

\section{Reference}

1. Zhao P et al. Novel function of PIWIL1 in neuronal polarization and migration via regulation of microtubule-associated proteins. Mol Brain. 2015;8:39. doi:10.1186/s13041-015-0131-0.

* Correspondence: xyuan@hussmanautism.org

${ }^{1}$ Institute of Neuroscience and State Key Laboratory of Neuroscience,

Shanghai Institutes for Biological Sciences, Chinese Academy of Sciences,

Shanghai 200031, China

${ }^{4}$ Current Affiliation: Hussman Institute for Autism, Baltimore, MD 21201, USA
Submit your next manuscript to BioMed Central and we will help you at every step:

- We accept pre-submission inquiries

- Our selector tool helps you to find the most relevant journal

- We provide round the clock customer support

- Convenient online submission

- Thorough peer review

- Inclusion in PubMed and all major indexing services

- Maximum visibility for your research

Submit your manuscript at

www.biomedcentral.com/submit

\section{() Biomed Central}









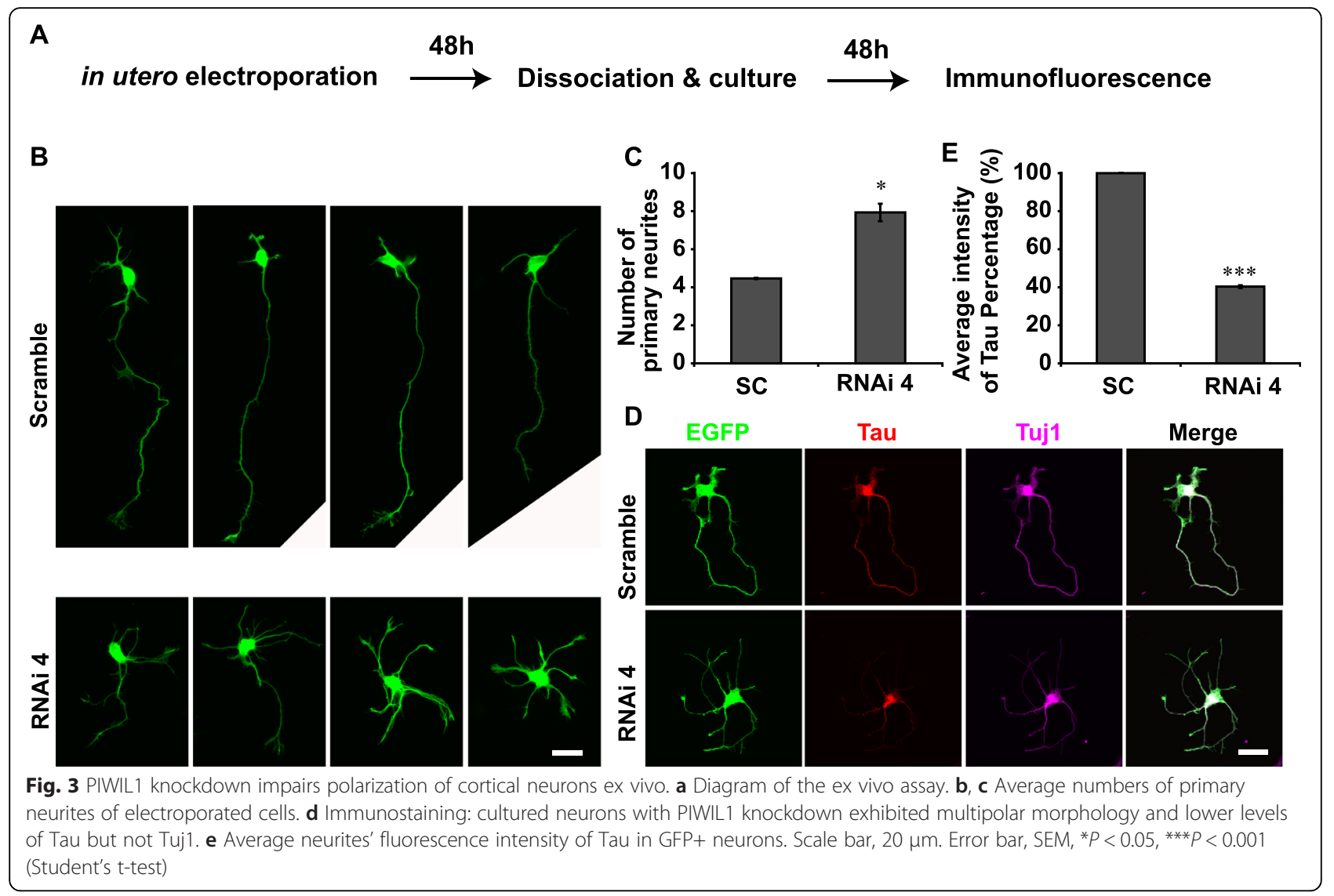

